Published in: Oxford Research Encyclopedia of

Politics, Sept. 2008. DOI:

$10.1093 /$ acrefore/9780190228637.013.195.

This is the penultimate version. Please cite the published version.

\title{
CRITICAL THEORY: self-reflexive theorising and struggles for emancipation
}

Fabian Freyenhagen (University of Essex)

\section{Article Summary}

'Critical Theory' is an umbrella term to denote those theorists that take up the task described by Marx as the self-clarification of the age struggles and wishes of the age. As such, two elements are crucial for it: (1) a connection to social and political struggles of emancipation; and (2) self-reflexivity.

Critical Theorists differ - sometimes quite fundamentally - about what these two elements require (and how they relate). For example, some such theorists (such as Max Horkheimer or Michel Foucault) take the normative orientations of struggles for emancipation as something that does not require grounding at the level of theorising, while others (such as Jürgen Habermas) think such grounding is the main task of Critical Theory, securing moral validity for the struggles. These substantive differences also mean that there are no accepted methods on which all Critical Theorists would agree. To stay with the example, those Critical Theorists who reject discursive grounding of its normative standards tend to engage in genealogy and other disclosing forms of social critique; while those who seek discursive grounding employ reconstructive and/or constructivist methods.

The existence of fundamental substantive and methodological differences among proponents of Critical Theory means that it is difficult, or perhaps even impossible, to give a uniform characterisation of it. Sometimes, Critical Theory is defined institutionally. Then it is denoting a succession of theorists (often classed into different generations) that are connected 
to the Institute of Social Research and/or the Philosophy Department in Frankfurt a.M., Germany - the so-called 'Frankfurt School'. However, this institutional definition has only limited use. The disagreements among thinkers within the Frankfurt School tradition can run deep - sometimes deeper than they run with theorists, like Foucault, not connected institutionally to it. And it is an open and contested question whether everyone institutionally connected to the Frankfurt School is engaged in Critical Theory. Thinking systematically about the task of self-reflexively connecting to struggles of emancipation requires a different approach.

It is helpful to understand Critical Theory as a broad and varied tradition, with core cases (such as Horkheimer's 1937 text 'Traditional and Critical Theory'), but no sharp boundaries. Understood that way, there cannot be a fully comprehensive treatment of Critical Theory, but it is possible to think of this tradition as involving multiple morphing sequences, whereby approaches are amended in various ways over time and thereby change into something else. One important dividing line is how historical or transcendental one takes Marx's task to be - some proponents of Critical Theory are, in effect, historical contextualists, while others seek to establish the conditions of possibility of human interaction as such.

Keywords: Critical Theory; Frankfurt School; Max Horkheimer; Jürgen Habermas; Axel Honneth; Michel Foucault; Rainer Forst; progress; communicative action; social irrationality; moral validity 


\section{Critical Theory}

'Critical Theory' is an umbrella term to denote those theorists that take up the task described by Karl Marx as 'the self-clarification (...) of the age struggles and wishes of the age' (1975: 209; see Fraser, 1989). As such, two elements are crucial for it: (1) a connection to social and political struggles of emancipation (existing or potential); and (2) self-reflexivity. Critical Theorists see themselves in continuity with (or even as part of) existing social and political struggles for emancipation. This does not mean that their relation to such struggles is an uncritical one. One common theme in Critical Theory is how ideology (in Marx's sense of socially produced false consciousness) is a hindrance to emancipation, for example because social arrangements lead people into having faulty perceptions of their needs and interests, which can then have the consequence that their protests are misdirected. Uncovering and criticising ideologies is one important aspect of the task of self-clarification of existing struggles - of the idea of Critical Theory (Geuss, 1981). To successfully complete this task requires a high level of self-reflexivity: about one's role as a theorist, the social context and function of theorising, and the critical standards and methods one brings to bear.

Critical Theorists differ - sometimes quite fundamentally - about what it means to stand in a connection with social and political struggles of emancipation and for their theories to be self-reflexive. For example, some such theorists take the normative orientations of struggles for emancipation as something that does not require grounding at the level of theorising, while others think such grounding is the main task of Critical Theory, securing moral validity for the struggles. There is also disagreement about how these two elements are interrelated - for example, if Critical Theory is understood as an integral part of the struggles, then its self-reflexivity is one of the struggles itself and tends to include reflection about the social context of theorising; if it is understood as more separate, then its self-reflexivity is often restricted to the theoretical endeavour alone and less sociological in nature. 
These substantive differences also mean that there are no accepted methods on which all Critical Theorists would agree. It is true that these theorists tend to work from a menu of four methods, each of which can be briefly glossed as follows:

- Genealogy denotes a range of approaches, but in the context of Critical Theory it tends to refer to those forms of critique that aim to denaturalise practices, ways of being a subject, and/or modes of enquiry by showing that these arose contingently out of configurations of power (or that they could have so arisen, for contingency can also be demonstrated by fictional histories). ${ }^{1}$

- Disclosive critique is a broader category that includes but is not restricted to genealogy (its other sub-categories are, for example, satire or dystopian pictures of where current trends could lead): the aim here is to show the world (or an aspect thereof) in a different light. $^{2}$

- Reconstructive social critique aims to uncover certain standards within social practices or presupposed by them, with which these can be evaluated. ${ }^{3}$

- Constructivism, characteristically, involves a decision procedure (or principle) with which to generate (or test) moral contents. ${ }^{4}$

\footnotetext{
${ }^{1}$ See also note 17 below.

${ }^{2}$ On the idea of a disclosing critique, see Honneth, 2000. One way to understand such critiques is that using them does not just involve rejecting discursive grounding for normative standards, but also rejecting the very idea that critique requires normative standards (see Vogelmann, 2017).

3 See also below the brief discussion in the main text for how Habermas and Honneth respectively use reconstructive methods.

${ }^{4}$ Constructivism is known from and dominant in contemporary political philosophy - officially, it is the method employed by Rawls, building on Kant (see Freeman (ed.) 2002: Chs. 3 and 9).
} 
But the uptake of these methods (and sometimes also how they are understood) is different among Critical Theorists. To stay with the earlier example, those Critical Theorists who reject discursive grounding of its normative standards tend to engage in genealogy and other disclosing forms of social theorising and critique; while those who seek discursive grounding employ reconstructive and constructivist methods.

The existence of fundamental substantive and methodological differences among proponents of Critical Theory means that it is difficult, or perhaps even impossible, to give a uniform characterisation of it. Still, it also means that there are rich and varied resources this research tradition has to offer. Studying Critical Theory opens up possibilities - notably possibilities to engage in political theory that go beyond the Rawlsian framework that is so dominant in liberal thinking since the $1970 s^{5}$

Sometimes, Critical Theory is defined institutionally. Then it is denoting a succession of theorists (often classed into different generations) that are connected to the Institute of Social Research and/or the Philosophy Department in Frankfurt am Main, Germany - the so-called 'Frankfurt School'. Max Horkheimer, Theodor W. Adorno, and Herbert Marcuse are then seen

\footnotetext{
${ }^{5}$ As is well-known, adherents to the Rawlsian framework (a) focus on justice and other moral notions (which they assign normative priority over ethical notions, like flourishing); (b) aim to develop a conception of justice for a perfectly just society by appeal to our considered judgements ('ideal theory'), and only on its basis provide guidance for imperfectly just contexts ('non-ideal theory'); and (c) operate with a strong division of labour between their normative theorising and the empirical social sciences. For all its variety, Critical Theory breaks with at least one and often two or even all three of these elements - giving higher prominence to ethics than Rawlsian theorists of justice; making existing struggles and social institutions the starting point and basis for theorising about our current social world, instead of ideal theory; and/or operating without a strong division of labour between disciplines, instead integrating normative theorising and social analysis.
} 
as key figures of the first generation; Jürgen Habermas as the leading figure of the second generation; and Axel Honneth as the most prominent member of the third.

However, this institutional definition has only limited use. The disagreements among thinkers within the Frankfurt School tradition can run deep - sometimes deeper than they run with theorists, like Michel Foucault, ${ }^{6}$ not connected institutionally to it. Indeed, it is an open and contested question whether everyone institutionally connected to the Frankfurt School is engaged in Critical Theory. Such an institutional connection is neither necessary nor sufficient for Critical Theory. Theorists from other institutional contexts have grappled with the task of self-reflexively connecting to struggles of emancipation, and thinking systematically about this task requires including them into the reckoning, along with critical reflection about whether those linked to that particular institutional context fall short of Critical Theory.

The approach taken here will not be in terms of institutional connection (although the main focus will be on Frankfurt School theorists). Instead the proposal is to understand Critical Theory as a broad and varied tradition, with core cases, but no sharp boundaries. This is to do justice to the fact that, as mentioned, even the two core ideas - self-reflexivity and connection to struggles of emancipation - are taken up in often radically different ways (both individually and how they are combined). Critical Theorists diverge as to what struggles they seek to stand

\footnotetext{
${ }^{6}$ On Foucault as a Critical Theorist, see, for example, Saar, 2007 and particularly Allen, 2016, who argues that Adorno and Foucault share a common perspective on the idea of progress that captures better what is required of Critical Theory (in terms of both self-reflexivity and connecting with struggles for emancipation, specifically post-colonial ones) than the works of Habermas, Honneth, and Forst. To draw a parallel between Adorno and Foucault (as, for example, Allen does) is not to deny that Foucault operated with his own distinctive methods. To mention just one example, Foucault's work tends to be immersed much more in actual historical discourses and their specific transformations than the more broad-brush treatment of history one finds in Horkheimer and Adorno's Dialectic of Enlightenment.
} 
in connection with; what this connection can and should be; what form self-reflexivity can and should take; and how self-reflexivity and connecting to struggles are meant to interact. Moreover, there will be new struggles to consider, and perhaps also new ways of understanding self-reflexivity. Consequently there, arguably, cannot be a fully comprehensive treatment of Critical Theory. It is, thus, not just restriction of space that means certain theorists associated with Critical Theory will not be discussed here (although space considerations come into it), but also connected to how it is understood. What is possible is to think of this tradition as involving multiple morphing sequences, whereby approaches are amended in various ways over time and thereby change ('morph') into something else. (To speak of 'morphing' leaves open whether or not the changes are a matter of progress or decline.) What is also possible is to present one or more of these morphing sequences by way of introduction to the tradition, while adding a health warning about non-comprehensiveness (as I have just done).

The starting point here will be a clear core case: Horkheimer's seminal text 'Traditional and Critical Theory' (henceforth 'TKT'). Then I will trace some of the ways the different elements of this seminal text are taken up by other theorists (notably Habermas and Honneth), and how Critical Theory morphed into different positions as a result. This is not the only morphing sequence there has been (or could be) within Critical Theory, but this one has attracted particular interest and controversy, and that is why it is the focus here.

\section{Horkheimer's 'Traditional and Critical Theory'}

In 1937, Horkheimer published a text that not just became seminal for what was later called the Frankfurt School, but is also of crucial importance for Critical Theory in general. As its title reveals, he draws a contrast between two kinds of theory - or, rather, two kinds of going about the practice of theorising, including the respective self-understandings at stake in these practices. The two kinds are described from a bird's eye perspective and are something like 
ideal types - the actual practices of theorising and their self-conceptions are only approximations of them; rarely (perhaps never) full instantiations.

For our purposes here, the following dozen features of Horkheimer's conception of 'Critical Theory' are important, and mark key differences to 'Traditional Theory':

1. Self-reflexivity about the social preconditions and functions of theorising. According to Horkheimer, the traditional conception of theory - not just in philosophy, but in all academic disciplines - largely disregards the social preconditions and functions of its own activity. In the pursuit of objectivity and impartiality, these matters seem of secondary importance - at best, they can be ignored altogether and, at worst, they are obstacles to be negotiated or conditions to be optimised, but even then, they, ultimately, leave the core of theorising untouched. In contrast, Horkheimer denies that the social preconditions and functions of theorising can be neatly distinguished from its content and nature - that intellectual processes can be 'detached from their matrix in the total activity of society' (TKT, 173/201). He requires Critical Theorists to reflect about what enables them to engage in their theorising, and what social functions and consequences it has; and to adjust it in the light of the insights gained this way.

2. Being part of the struggle for emancipation. Reflecting about Critical Theory's social functions reveals that the Critical Theorist's 'profession is the struggle of which his own thinking is a part and not something self-sufficient and separable from the struggle' (TKT, 190/216). ${ }^{7}$ Traditional Theory, in contrast, is - whether

\footnotetext{
7 One issue in this context is what happens to Critical Theory when the struggles for emancipation have disintegrated and/or been repressed. Horkheimer in 1937 still speaks of the proletariat, but his confidence in this class is clearly shaken, noting how truth has taken refuge in small groups of individuals, themselves decimated
} 
intentionally or not - part of the status quo, producing and reproducing it. (Producing it insofar as existing practices are often dependent on theories and their categories, such as notably economic ones; and reproducing it insofar as Traditional Theory cements these practices and the dominant ways of seeing and understanding the world, either by lending direct support to them or by failing to criticise them adequately.)

3. Radical social critique. Emancipation, for Horkheimer, requires overcoming the modern capitalist social world, for it is an 'inhuman world' and the misery it produces 'is necessarily connected with the way in which the social structure is organized' (TKT, 178, 180/204, 207). It is beyond reform; requiring transformation. This is an 'existential judgement' (TKT, 201/227), in the unfolding of which Critical Theory consists (in contrast to Traditional Theory which consists in hypothetical judgements that still need to be applied to reality).

4. Theorising as partisan (rejection of neutrality). As part of a struggle, Critical Theory is not a neutral endeavour, but partisan, guided by the 'concern [Interesse] for the abolition of social injustice' (TKT, 216/242). This is not to say that Traditional Theory - in contrast to Critical Theory - is neutral. There is no theory 'that does not contain political motivations, and the truth of these must be decided not in supposedly neutral reflection but in ... concrete historical activity' (TKT, 196/222). Rather, Traditional Theory is insufficiently self-reflexive about its own partisan nature: it does not own up to the fact that it - however inadvertently -

by state terror (TKT, 211/237f). I come back to this issue briefly below, but note here already that Critical Theory's relation to struggles for emancipation could contain initiating such struggles, rather than merely connecting to existing ones. 
maintains the existing social world, rather than furthering the cause of emancipation. It operates (at least implicitly) with a division between being a theorist (or scientist) and a citizen; and this division neglects that we cannot but be political, even when it comes to seemingly apolitical choices between different scientific methodologies. ${ }^{8}$

5. Self-critical. Being a self-reflexive partisan requires relating critically not just to the social world, but to oneself and the struggle of which one is part. It is not the case that the wishes and beliefs of, say, the proletarians are simply taken by Critical Theory as unquestionable givens; they need to be scrutinised critically too. For 'It is possible for the consciousness of every social stratum today to be limited and corrupted by ideology' (TKT, 216/242; my emphasis). Identifying and counteracting false consciousness and blind spots is not just a task vis-à-vis others, but theorists also (or perhaps even particularly) need to direct such critical scrutiny onto themselves, checking, among other things, for constricted imagination. As Geuss puts it: 'Whatever questions I might put about claims my interlocutor makes, I must also put the very same questions to myself with exactly the same or even greater rigor' (2009: xi; emphasis in the original).

6. Historical constitution of subject (and object). Like Kantian critical philosophy, Critical Theorists insist that the object and subject of cognition are pre-constituted; but, unlike Kant, they think that this pre-constitution is socio-historical (not a priori): 'The facts which our senses present to us are socially preformed in two ways: through the historical character of the object perceived and through the

\footnotetext{
${ }^{8}$ For an example of demonstrating the political dimension(s) of seemingly neutral methodological moves in contemporary political philosophy, see Finlayson, 2015.
} 
historical character of the perceiving organ' (TKT, 174/200). ${ }^{9}$ To take an example from Art History in relation to the latter: even though our physiological apparatus of perception is probably unchanged since the $15^{\text {th }}$ century, the cognitive style by which we interpret an Italian Renaissance painting is different from the one by which its producers and viewers at that time will have seen it; or, indeed, how it would have been seen by someone from China during the same period (Baxandall, 1988). The respective 'period eyes' would be different, related to a different capacity to discriminate between, for example, grades of ultramarine paint (a particularly valued and expensive material in early $15^{\text {th }}$ century Italy). One important consequence of the historical constitution of the subject is that 'No one can turn himself into a different subject than he is at this historical moment', meaning that we should reject 'the assumption of an absolute, trans-historical subject or the possibility of substituting subjects, as though a person could remove himself from his present historical juncture and truly insert himself into any other he wished' (TKT, 213-4/240; translation amended).

7. Rejection of the dominant normative standards. In part because of the historical constitution just mentioned and as expressive of the Marxist idea that the ruling ideas are those of the ruling classes, Critical Theory does not take the dominant normative standards as unquestionable givens. Instead, it 'is suspicious of the very categories of better, useful, appropriate, productive, and valuable, as these are understood in the present order, and refuses to take them as nonscientific presuppositions about which one can do nothing' (TKT, 180-1/207).

\footnotetext{
9 This kind of historicising of Kant's transcendental philosophy is also what Foucault, at least on some interpretations - see, notably, Han-Pile, 2002 - aims to do.
} 
8. Negativism. This has several aspects, not all of which are clearly explicit in the 1937 text. It is helpful to make them explicit and articulate them separately, for they need not always form a package (for example, Honneth accepts $8 \mathrm{a}$, but not 8b-d).

a. Methodological negativism: this is the view that we should start with negative aspects of existing social reality - as Horkheimer puts it, 'the misery of the present' (TKT, 190/217; translation amended). Instead of constructing or turning to a positive ideal (as in those approaches that make 'ideal theory' central), theorising arises out of and engages directly with the problems and crises of the existing social world. One may, eventually, build up a positive picture of an alternative from there (as much as this is possible); but this is neither logically nor normatively required as a first step. To take an analogy from a different field: contrary to common expectations and pronouncements, medical research does not begin with a conception of health, but studies illnesses first and then constructs a conception of health from this (see Canguilhem, 1989).

b. Substantive negativism: as noted above, Critical Theory consists in the 'existential judgement' that the present social world is inhuman. As such, this world is realising what is bad for human beings (rather than what is good) - it is substantively negative.

c. Epistemic negativism: history and our contemporary situation have familiarised us with what is bad for human beings. But knowing the misery of the present (and past) does not suffice to know what a possible future society that had overcome this misery positively involves (TKT, 190-1/2167; NB: the English translation misses here a whole sentence from the original German version). 
d. Metaethical negativism: the misery of the present suffices on its own to provide us an interest in a different social world and for the demand to strive for it; we do not have to invoke a positive alternative or a conception of flourishing (see Freyenhagen, 2013: esp. Ch. 8).

9. Social irrationality (and a dual conception of rationality). Critical Theory presents the existing society not just as unjust, but as irrational. It operates with a Hegelian notion of reason: reason is not just a capacity of individuals, but exists in social practices (TKT, 177/204). These practices (and society as a whole) are normgoverned and have internal teloi, to which they can fail to live up in various ways and to various extents (see Honneth, 2009: Ch. 3, section I; and 2015; Jaeggi, 2014). In later writings, Horkheimer introduces a dual notion of rationality to make this point, such that the modern social world is both highly rational in one sense ('instrumentally rational', where this includes not just efficiency in deploying means, but also successfully imposing a highly systematised classificatory system onto the world and shaping it accordingly); while being irrational in another sense ('objectively irrational' in, on the one hand, having produced the material conditions for a different social world that could be controlled collectively by human beings in a way that would free them from misery; but, on the other hand, dominating them and systematically generating misery instead of making way for this different social world).

10. Interdisciplinary focus on social processes, not (mere) normative theorising. Critical Theory's contribution to the struggle for emancipation is not about doing the normative legwork in near isolation of social analysis. Indeed, there is no need for 'academic instruction' about 'choosing among revolutionary, liberal and fascist ends and means' (TKT, 196-7/223). Instead, Horkheimer understands Critical 
Theory as continuation of Marx' critique of political economy, analysing social processes that hinder emancipation and the negative experiences they generate (see already 8 a above). Its approach is, as a result, interdisciplinary. ${ }^{10}$

11. Holism. Critical Theory forms a package; one cannot simply isolate one element and present it as sufficient for Critical Theory- not even as important an element as ideology critique (see Horkheimer's comments on research into ideologies as a specialised enquiry; TKT, 183/209). To take an example from the 2016 US presidential campaign, when Trump or his supporters reveal the way their opponents' views are intimately connected to certain interests and influenced by lobbies (say, teacher unions), then this does not yet make them Critical Theorists. Similarly, one cannot take one element and confirm its validity on its own - Critical Theory stands and falls as a whole, and it is as part of that whole that the specific elements acquire their proper meaning and function (TKT, 201-2, 215/227-8, 242).

12. Historical variability. In being tied up with social analysis and the struggles of the age, Critical Theory is not unchanging, but adapts as social reality and social struggles change over time. This connects with the holism: if one takes isolated elements from two different phases of Critical Theory, then they may well stand in contradiction with each other, while, at the same time, the wholes of which they are part can form a continuous line of the ever-developing existential judgements that

\footnotetext{
${ }^{10} \mathrm{It}$ is an interesting question of how interdisciplinary the first generation of the Frankfurt School remained after the 1930s, and how integrated its more empirical work (which continued beyond the 1930s) and theoretical work actually was. For example, one might think that especially Adorno reasserted the importance of philosophy as a self-standing theoretical endeavour (notably in the 1960s), but the picture is, arguably, more complicated than this (see Freyenhagen, 2017a). Among other things, he did not think of philosophy as providing discursive foundations for struggles of emancipation (see Freyenhagen, 2013 and 2017b).
} 
Critical Theory consists in (TKT, 207-16/233-43). One difficult question is whether such continuity is maintained or the changes made to theorising are so substantial that it is no longer Critical Theory, properly speaking.

Returning to the contrast to Traditional Theory, we can sum up that it either (a) does not reflect on its social context and presuppositions; or (b) takes itself to be value-free and/or non-partisan, often distinguishing sharply between the role of the theorist and his/her other roles (notably the role of politically active citizen); or (c) both. Traditional Theory also tends to operate with a (purported) transhistoric notion of truth and the subject; to be atomistically (rather than holistically) understood; (if engaged in explicit normative theorising at all) to make reference to positive ideals and be reformist; and to operate with a strict division between disciplines. As noted earlier, there probably is no one theory that is traditional in all of these senses, but we can think of neo-classical economic theory or Luhmann's "system theory" as instances of Traditional Theory.

\section{Morphing Sequences: Habermas and His Aftermaths}

The above dozen elements capture the key points of how Horkheimer conceived of Critical Theory in 1937. Subsequently, different theorists (including, arguably, the later Horkheimer) modified the view what it was to engage in 'the self-clarification of the struggles and wishes of the age'. In part, this was because the age changed - and repeatedly so, with first WWII and the full unfolding of the Nazi extermination machine, then the cold war period of restoration, followed by further changes to society and social struggles. However, in part the characterisation of Critical Theory changed because theorists took Horkheimer's 1937 view to give rise to various difficulties at a theoretical level that required revisions to the overall project. Often, these revisions are presented as improvements in an on-going learning process, 
but this is not universally accepted. Here, I indicate some of these developments in terms of multiple morphing sequences instead. (Morphing sequences, to recall, involve often very small and initially imperceptible changes that eventually result in significant differences compared to the starting point - such as when an image of one face is transformed gradually into one of another face or, more radically, of a non-human animal or even an inanimate object. Morphing sequences depict change without implying progress or decline.)

\section{The Case of Habermas}

The revisions undertaken by Habermas - often described as the leading light of the secondgeneration of the Frankfurt School - were most influential, and it is a sketch of them that we should turn first. Restrictions of space make it impossible to trace the various transformations of Habermas' own theory, so instead the focus is on his mature position. It is helpful to think of this position as arising from one fundamental change to Horkheimer's 1937 conception, and then to consider how that change leads to repercussions in relation to the other elements enumerated above as features of Horkheimer's 1937 Critical Theory.

Habermas main worry is that Critical Theory as understood by Horkheimer (and also Adorno) lacks ‘normative foundations' (1984: 374). Such foundations are necessary because we cannot - here Habermas agrees with 7 above - simply accept the socially dominant normative standards. We also cannot simply rely on the existing struggles, which - as national socialism and fascism demonstrated - can be co-opted and channelled into deeply problematic directions. Most importantly of all, Horkheimer's claim about the growing irrationality of society deprives him of the resources with which to criticise that instrumental reason is becoming absolute. What we need is an independent normative foundation. Ideally, such a foundation should be of the sort that could - at least in principle - remain available whatever specific contents the struggles and wishes of the age would take (i.e., be accessible to individual subjects - say by using their rational faculties - even under a fascist regime which co-opts the 
struggles and shapes people's wishes). In this way, Critical Theory has a more secure basis than merely asserting that truth has taken refuge with a group of individuals (see 2 above) - it can demonstrate its right to criticise and on what normative resources it can draw.

Habermas's proposal (in his mature works) is that normative resources are buried in the very idea of discourse, and available in every communicative act. Insofar as we are talking about dialogue at all, the participants are unavoidably committed to the goal of mutual understanding on the basis of reasons - whatever they may say to each other, the very act of engaging in communicative action places them under certain normative demands, to which they can (and, to be sure, often do) not live up to, but which are incurred by them (however inadvertently) nonetheless. In short, we can and should have recourse to communicative rationality.

This move might, initially, seem like it is just adding an additional element to the twelve features of Horkheimer's 1937 characterisation of Critical Theory - a normative foundation for Critical Theory that holds independent from it (universal pragmatics). But closer inspection reveals this not to be so. One way to think about this move is to understand Habermas to relax the thesis of the subject's historical constitution (see 6 above). In a return to something more like Kant's position, Habermas reintroduces transcendental claims: however human beings are formed by their social context, there is anyway an implicit rational standard contained in every human communicative act and we can know about this standard thanks to universal pragmatics. Moreover, once we have realised that there is this standard, we no longer need to reject neutrality and commit to partisanship (see 4 above), but instead can understand theorising as impartial (at least in ambition). This, in turn, changes also the relationship to the struggles for emancipation (see 2 above). Theorising is no longer directly part of these struggles, but rather consists in rational reconstruction - that is, it consists in uncovering the rational core of these struggles. (In Habermas's case, rational reconstruction actually extends further: it concerns the 
rational core of human interactions more generally, not just of struggles of emancipation; and, in a secondary use, it concerns historical developments such as the modern liberal-democratic state, with its rule of law and constitutional principles.) The division of labour between the theorist and the citizen is reintroduced - in Habermas's case this duality is notably visible in the way he divides up his own extensive opus into works of the philosopher engaged in foundational theorising and works of the public intellectual engaged in political debate. The idea of theorising as providing normative foundations also breaks with Horkheimer's holism (feature 11 above), and the recourse to communicative action and its presuppositions also means that negativism (feature 8 above) is abandoned in all four of its aspects. Interdisciplinarity (feature 10 above) survives as part of the theoretical endeavour for Habermas, but in his mature works the mix of disciplines and research traditions changes compared to first-generation Frankfurt School thinkers and Habermas' own early work (with psychoanalysis' and Marxism losing their central role, and pragmatism, semiotics, and even system theory becoming part of the newly configured constellation).

What Habermas and his followers would argue is that his reconfiguration of Critical Theory is motivated by two of its key features that they hold onto: self-reflexivity about social conditions and functions of theory (feature 1 above) and a self-critical questioning of one's own presuppositions (feature 5). Habermas argues that Horkheimer (and Adorno) have manoeuvred Critical Theory into a position of an unresolvable contradiction between commitments ('an aporetic situation' (1987: 128)): both claiming that instrumental reason's reign has become total and criticising this reign in a way that requires a different notion of reason. Habermas thinks that a retreat from some of the features of how Horkheimer (and Adorno) conceived Critical Theory is necessary to withstand critical scrutiny of the function(s) it can play and its normative standards. Debates about whether or not it was necessary continue. For our purposes here the more immediate point is that by making a certain addition, Habermas 
morphed Critical Theory into something significantly different from what Horkheimer had proposed in 1937.

Going into the details of Habermas' theory would lead us to far here, but three important points should be highlighted as they have particular importance for our context. First, one further element that Habermas retains from Horkheimer's 1937 characterisation of Critical Theory is the claim about social irrationality (feature 9 above). However, along with the other transfigurations, there is an important revision here too. The basic thought figure survives largely untouched: society can be irrational despite being rationally organised. Like with Horkheimer, a dual notion of rationality allows us to make sense of this otherwise perplexing claim, but the difference in Habermas's case is that he reconfigures this dual notion. Functionalist and communicative rationality replace Horkheimer's instrumental and objective reason respectively. ${ }^{11}$ Moreover, social irrationality is understood in a reconfigured way: the claim is no longer that capitalist modern society is irrational as such, but rather that it can be rational as long as functionalist reason operates within its appropriate sphere (called 'system' by Habermas and made up of the market and administrative apparatus) and does not came to govern - or as Habermas tends to put it, 'colonize' - the 'lifeworld' (the action sphere where symbolic reproduction of society occurs, and communicative rationality should reign supreme). ${ }^{12}$ Here we also see that (with the mature works of Habermas) a more reformist element enters into the reconfigured Critical Theory (in contrast to feature 3 above).

\footnotetext{
${ }^{11}$ Each of these notions has been briefly introduced earlier, bar functionalist rationality. The core idea regarding the latter is that there is a rationality that does not operate by way of the conscious intentions of agents (like, at least according to Habermas, both instrumental reason and communicative rationality do), but 'the economic and administrative systems themselves act as the transmitter of the system-maintaining imperatives' (Cooke, 2013: 54).

${ }^{12}$ For the fuller picture, see Habermas, 1984: Part VIII; and the excellent discussion in Jütten, 2011.
} 
Second, it is important to recognise that normative foundation for Habermas does not automatically mean moral foundations. He has proposed a moral theory for individual action his discourse ethics - and its fundamental principle - principle $(\mathrm{U})^{13}$ - is (meant to be) a moral principle. But it is not the foundation of his theory in general or even of his political theory in particular - contrary to the reading many commentators adopted before the publication of Between Fact and Norms (Habermas, 1996; see also Finlayson and Freyenhagen, 2011). Rather, the foundational principle is the principle of discourse (D), which states that 'only those norms are valid that could meet with the assent of all those potentially affected, insofar as they participate in rational discourse' (Habermas, 1996: 107). This principle states, according to Habermas, the necessary but not sufficient condition of the validity of any norm, and is reconstructed from what it takes to engage in human communication at all. It can the then be supplemented to derive principles for specific discursive practices. What has to be added is the particular form in which validity operates in those practices. To take the most relevant case for our purposes here, rational reconstruction of politics reveals that for coercive power to be legitimate it has to be lawfully exercised, so the form of the law has to be added to principle of discouse to derive the relevant principle. The resulting construction, called 'principle of democracy', states: 'Only those statutes may claim legitimacy that can meet with the assent of all citizens in a discursive process of legislation that in turn has been legally constituted' (Habermas, 1996: 110). Critical Theory and also political practice (whether by public intellectuals or other citizens) can draw on this principle for engaging critically both with

\footnotetext{
${ }^{13}$ Principle (U) states that: 'a norm is valid if and only if the foreseeable consequences and side effects of its general observance for the interests and value-orientations of each individual could be freely accepted jointly by all concerned' (1998: 42; translation amended to include the biconditional of the German original; emphasis in the original.).
} 
specific policies and with the institutional set-up that give rise to them. For example, drawing on the first point above, one way our society can be irrational is for its statutes to have met the assent only of the major corporations that have lobbied parliaments and bought influence by way of campaign finance and other means. Here our purportedly democratic institutions are colonized by economic imperatives and betray their rational potential.

Third, Habermas tends to oscillate between weaker and stronger versions of the reconfigured Critical Theory he espouses. The way I have been presenting his theory so far suggests that he is making strong claims about human communication as such - that he engages in a kind of formal anthropology with transcendental claims. However, it is neither clear whether this endeavour is (or could be) successful, nor that this really is what Habermas is doing. As to the former, critics have pointed out that what he presents as universal pragmatics, in fact, relies on key aspect of a distinctively modern and Western social context (see notably Cooke, 1994 and, more recently, Allen, 2016). As to the latter, sometimes Habermas seems to understand his account more along 'quasi-transcendental' grounds - to speak with Foucault: he is investigating and presenting only the presuppositions of the historical a priori of Western modernity, not the transcendental conditions of human interaction as such. ${ }^{14}$

\footnotetext{
14 The second, more historical contextualist reading of Habermas's project can draw support from his post-1988 writings $(1992 ; 2002 ; 2008 ; 2017)$, in which ethical considerations with metaphysical underpinnings, most notably religion, are not presented as simply superseded, but instead play a significant role to enrich modern discourses of validity. The latter's formal nature and separation from each other represent achievements, but they also suffer from a loss of meaning and accompanying motivational power. It is, thus, unsurprising that Habermas, contra Rawls, insists that the duty of translating religious convictions into public reasons lies with the secular citizens and with office-holders, not with the person uttering these convictions - although, officially, the argument is run in terms of burdens of fairness (2008: Ch. 5).
} 
This final point is particularly relevant for understanding how the morphing sequences of Critical Theory unfold after Habermas (and, in good part, in reaction to his reconfiguration of it). Broadly speaking we can identify a more Kantian and a more Hegelian way in which Habermas has been taken up. The more Kantian line is being advocated particularly by Rainer Forst (notably 2012), drawing on both Habermas and Rawls. Forst upholds many of Habermas's changes to Horkheimer's 1937 characterisation of Critical Theory, but reconfigures the normative foundation element. Instead of turning to a non-moral normative foundation in universal pragmatics, he offers a moral one: the assent of all those potentially affected is now required because everyone is, according to Forst, owed a basic (moral) right of justification. Once again, this line of argumentation is open to the objection that what might be true about the normative presuppositions of a certain modernity is not automatically true about human beings irrespective of the social context they live in (see Allen, 2016: Ch. 4). These considerations may push one more towards a Hegelian way to take up Habermas. A prime example of this is Honneth's reconfiguration of Critical Theory.

\section{The Case of Honneth}

While Honneth follows Habermas in making discursivity and context-transcending moral validity central to Critical Theory, he does partially reverse some of Habermas's reconfiguration of Horkheimer's 1937 characterisation of Critical Theory. In particular, Honneth seeks to reconnect Critical Theory again more with actual struggles for emancipation (feature 2 above in section I), and restores also the element of methodological negativism (feature $8 \mathrm{a}$ ) because he makes negative experiences that motivate these struggles the starting point for Critical Theory. Instead of the presuppositions of human dialogue at such, Honneth, initially, concentrates on reconstructing 'the moral grammar of social conflicts' (Honneth, 1992 ) - that is, on unearthing the moral commitments and categories of the various actors in these conflicts (why they enter struggles, how and when they consider these struggles to be 
successfully completed, etc.). During this phase, the focus on recognition already betrays a stronger Hegelian influence, but initially Honneth still aims to operate at the level of formal anthropology, drawing - not unlike the early Habermas - heavily on psychoanalysis and Mead's pragmatism. The Hegelian take-up of Habermas comes even more to the fore in Honneth's more recent work (notably Honneth, 2015), on which I will concentrate here.

In analysing social struggles of modern times, and the institutions central to modern liberal societies changing in response to these struggles, Honneth argues that one particular norm operates as the meta-norm with reference to which social practices are evaluated in terms of how fully they realise this norm. This norm is freedom. That may not strike one as a particularly distinctive claim. What makes Honneth's claim distinctive is the way he combines Hegel and Habermas in configuring this freedom. For Honneth, modernity's fundamental norm is the freedom of the individual not just in the negative sense of freedom, nor even just in the sense of autonomy as reflective freedom (in the sense of Frankfurt and Dworkin). ${ }^{15}$ Rather, the norm of freedom operative in social struggles and aspired to in modern social practices is 'social freedom', whereby (this is the Hegelian element) my freedom is intertwined with everyone else's freedom in such a way that it only exists if this intertwining is recognised by us, where this in turn (and this is the Habermasian element) requires that our practices are configured in such a way that all those affected by them can assent to their results in virtue of rational discourse(s). To take a particularly striking example, Honneth celebrates consumer cooperatives - that is, co-operative organisations, which involve (aspirations to) three elements: (a) the discursive formation of needs and preferences of its members (including collective

\footnotetext{
${ }^{15}$ In true Hegelian fashion, both of these senses of freedom, while they represent only a one-sided and insufficient explication of modernity's meta-norm, still need to be given their due (such as by way of individual rights to privacy and freedom of conscience).
} 
decisions to forgo certain consumption choices, such as alcohol); (b) the collective power to be a bastion against pernicious influences by corporations and in directing production towards the discursively formed needs and preferences; and (c) in distributing goods secured according to fairness considerations, not ability to pay (2015: section 6.2.2). Such co-operatives developed in the late $19^{\text {th }}$ Century and early $20^{\text {th }}$ Century, but have been in decline since then and only exist as remnants (such as employee-owned supermarket chains). For Honneth, who laments their decline, they are good examples of what social freedom consists in - not just the individual freedom to consume without interference from others; nor just consuming what I can reflectively endorse as part of my existing psychological structure; but consuming in a way that involves a mutual concern for others and a discursively developed set of consumption choices.

What is striking here is the shift in methodology. Both Habermas and Honneth employ reconstruction, but they do so in different ways. While Habermas's 'rational reconstruction' focuses on the presuppositions of social interaction as such, ${ }^{16}$ Honneth's 'normative reconstruction' has a more specific object: modern 'democratic ethical life'. The former aims to uncover the norms operative in any linguistically mediated social practice; the latter the norms that are required for modern liberal-democratic societies to reproduce themselves. Instead of the discourse principle as implicit presupposition of any human communication, we get historically indexed norms - honour for feudalism, social freedom for modern society.

\footnotetext{
${ }^{16}$ Gauss argues that Habermas also uses rational reconstruction in another way, namely, rationally reconstructing (by way of a thought experiment) how the democratic constitutional state can be seen as the outcome of a learning process, 'as a rational response to the fundamental problem of generating order under the conditions of a modern, increasingly reflexive societal consciousness' (2013: 564). Honneth's normative reconstruction is more sociological and historical, and more future-directed.
} 
Moreover, rational reconstruction in Habermas is central for securing moral validity, whereas for Honneth, it is a separate matter to establish moral validity. Starting with the historically situated norms of societies and epochs brings the advantage of connecting normative theorising from the beginning with social analysis and existing motivational resources of individuals and groups. But, according to Honneth, it cannot suffice:

'Current attempts to overcome the deficits of Kantian theories of justice that ignore existing institutions nearly always attempt to hermeneutically adapt normative principles to existing institutional structures or prevailing moral beliefs, without proving whether the substance of these institutions is itself rational or justified' (2015: 2).

Once the reconstructed norms have been morally validated (about which I say more below), it is then possible to bring them to bear as part of an imminent social critique, probing 'the extent to which ethical institutions and practices do not represent the general values they embody in a sufficiently comprehensive or complete fashion' (Honneth, 2015: 10). For example, insofar as the health care system of the UK is committed to the norm 'free at the point of need' - as a specification of what social freedom requires - then reforms to it that erode or threaten this norm could be criticised as moving us further away from the normative orientation of this practice. Such a development would be make the UK less rational (in the sense of social irrationality typical of Critical Theory, but here understood in reference to the normative potential of social practices, not communicative rationality or objective reason).

Securing moral validity of the societal norms also is different in Honneth's case compared to Habermas's. Initially, Honneth even suggests that genealogy could be the 
supplementing method to secure validity. ${ }^{17}$ In his most recent work, validity is meant to be secured by a non-metaphysical philosophy of history. The question of moral validity of social norms is not acceptability of their consequences and side effects by all concerned (as in Habermas' case), but secured by the (purported) transcendental presupposition of participating, or at least not rebelling against, the social practices and institutions' embodying these norms. Such participation (or non-rebellion) requires, according to Honneth, that we see the norms in question as 'normatively superior to historically antecedent social ideals' (2015: 5; see also 2009: Ch. 1). To secure moral validity this move is then combined with Honneth's version of the Hegelian end of history thesis, according to which it is inconceivable that we could improve on social freedom as a (meta-)norm of society (Honneth, 2015). The overall strategy of moral validation and its elements (the commitment to moral progress and the thesis of an end to normative history) remain controversial within Critical Theory (see Allen, 2016; Freyenhagen, 2015; and Schaub, 2015).

One further noteworthy difference to Habermas is how Honneth understands the functional differentiation of society. Instead of a two-fold differentiation into lifeworld and system, Honneth broadly follows Hegel's threefold functional differentiation into family, civil society, and the state: there are (A) relationships (and associated practices) of friends, family members and lovers; (B) market relationships (and practices) as producers and consumers; and (C) relationship (and practices) as citizens of a state. Each of these three operates with a specific

\footnotetext{
17 'Reconstructive Social Criticism with a Genealogical Proviso: On the Idea of "Critique" in the Frankfurt School' [2000], reprinted in his 2009: Ch. 3. Honneth's use of the notion of genealogy is somewhat unusual. What he endorses here is genealogy in the sense of investigating whether a value has been eroded or hollowed out over time, not in its usual sense within Critical Theory - that is, as aiming to denaturalise practices, ways of being a subject, and modes of enquiry by showing that they arose contingently out of configurations of power. For an excellent discussion of genealogy in the latter sense, see Saar 2007.
} 
version of the meta-norm of social freedom. This is true, for Honneth, even of the market (at least in aspiration) - contrary to how markets tend to be characterised, including by Habermas (see Jütten, 2015; and Honneth, 2015).

In reacting to Honneth's work, authors within the Critical Theory tradition have taken different paths - either trying to explore further how to combine Hegel and Habermas (for example, Jaeggi, 2014); or by continuing the Kantian, constructivist strand in Habermas (like, as already mentioned, Forst does); or by taking an even more historicist line than Honneth (notably Allen, 2016). This is not the place to trace these developments further; suffice to note that the debate about how Kantian or Hegelian (or, indeed, Nietzschean) Critical Theory ought to be, continues.

\section{Looking Ahead}

We have now seen how Critical Theory includes a variety of approaches, which stand in a combination of continuity and discontinuity to each other. This, inevitably, was only a small selection - there are difference among the first-generation thinkers of the Frankfurt School or even between the earlier and later Horkheimer; there are alternatives to Habermas's take up of the 1937 characterisation (notably Adorno's later work, and those of his students, such as Oskar Negt and Alexander Kluge, but also by Albrecht Wellmer and others); there are other reactions to Habermas (notably by Nancy Fraser and Seyla Benhabib); and there are parallel developments in the French and Italian contexts not initially influenced by Horkheimer's work; and so on.

Critical Theory remains a living research tradition, and the morphing sequences will continue. The core orientation remains Marx's idea of the self-clarification of the struggles and wishes of the age. Among the struggles that theorists within this tradition have tried to integrate has been feminism (see notably Fraser, 1989 and Allen, 2008). Among the challenges of the age that have received special attention has been globalisation and questions about international 
institutions (including regional ones like the EU), norms, and practices (see, for example, Habermas, 2012; and Forst, 2012: Part 3). This also includes work on migration (for which Benhabib, 2004 provided an important impetus). But so far there has been relatively little on the environmental crises and the social struggles related to it (see Parr, 2014 for an exception). Debates rage on about whether a justificatory programme is the central theoretical task of Critical Theory (see Forst, 2017; and Freyenhagen, 2017b), and whether or not Critical Theory can (and should) do without a commitment to moral progress (see Allen, 2016; and Forst, 2017: Ch. 4; see also Owen, 1992; Iser, 2008; McCarthy, 2009). Another on-going debate concerns the role and function of the theorist, and how to avoid succumbing to an authoritarian picture whereby an elite of theorists confronts the ideologically misled masses (for example, Celikates, 2018; and Ypi, 2012: esp. Ch. 2). The relationship between Frankfurt School Critical Theory and Post-Structuralist Critical Theory continues to be a matter of concern (see, for example, Cooke, 2013), and more recently questions about its relationship to Postcolonialism (Allen 2016) and Critical Race Theory (Mills 2017) have been raised. There are renewed attempts to connect Critical Theory with actual struggles (such as Robin Celikates's work on civil disobedience (for example 2016)); and the assault on democracy and the public sphere are natural topics for Critical Theorists to analyse and counteract (see, recently, Brown, 2015; and earlier, Crouch, 2004).

There has been an uptick of interests in renewing Critical Theory's thesis about social irrationality. In particular, the idea that a society with (social) rationality deficits is pathological or sick, has got renewed attention - in short, the idea of social pathology (Laitinen et al., 2015; Freyenhagen, 2018). Using this idea to frame social critique makes for a distinctive approach to social problems - notably, it is different from the narrower focus on justice and legitimacy dominant in political theory and especially Rawlsian political philosophy. It also necessitates a resurrection of the interdisciplinary programme of combining critical theorising with social 
analysis. Some of the most recent development in quantitative social sciences (particularly in relations to the social determinants of health) have started to make use of the same imaginary and conceptualisation. For example, Stuckler and Basu (2013) have argued that austerity, rather than being a cure, is making the body economic sick, causing excess deaths and detrimental health outcomes. But as of yet, there exists too few bridges between the sophisticated tools of contemporary social science and the conceptual resources and insights of Critical Theory. This remains an area in need of development, along with a response to the environmental crises and the introduction of new technologies and their interaction with social control (such as big data and the way it is and will be used by corporations and governments).

Critical Theory can only remain alive as the self-reflexive theoretical work that is connected with struggles of emancipation by constantly renewing itself. The task of their selfclarification remains on-going.

\section{References}

Allen, Amy (2008). The Politics of Our Selves: Power, Autonomy, and Gender in Contemporary Critical Theory (New York: Columbia University Press).

Allen, Amy (2016). The End of Progress: Decolonizing the Normative Foundations of Critical Theory (New York: Columbia University Press).

Baxandall, Michael (1988). Painting and Experience in Fifteenth-Century Italy (Oxford: Oxford University Press, second edition).

Benhabib, Seyla (2004). The Rights of Others (Cambridge: Cambridge University Press).

Brown, Wendy (2015). Undoing the Demos: Neoliberalism's Stealth Revolution (New York: Zone Books).

Canguilhem, Georges (1989). The Normal and the Pathological, trans. C. R. Fawcett with R. S. Cohen (New York: Zone Books). Originally in French [1943, 1966]. 
Celikates, Robin (2016). 'Rethinking Civil Disobedience as a Practice of Contestation Beyond the Liberal Paradigm'. Constellations 23(1): 37-45.

Celikates, Robin (2018). Critique as Social Practice: Critical Theory and Social SelfUnderstanding, trans. by N. von Steenbergen (London (etc.): Rowman and Littlefield). Originally in German [2009].

Cooke, Maeve (1994). Language and Reason: A Study of Habermas's Pragmatics (Cambridge, MA: MIT Press).

Cooke, Maeve (2013). Re-Presenting the Good Society (Cambridge, MA: MIT Press).

Crouch, Colin (2004). Post-Democracy (Cambridge: Polity Press).

Finlayson, Lorna (2015). The Political is Political (London (etc.): Rowman \& Littlefield International).

Finlayson, James Gordon and Fabian Freyenhagen (2011). 'Introduction; The HabermasRawls Dispute - Analysis and Reevaluation'. In: idem. (eds.), Habermas and Rawls (London (etc.): Routledge).

Forst, Rainer (2012). The Right to Justification, trans by Jeffrey Flynn (New York: Columbia University Press). Originally in German [2007].

Forst, Rainer (2015). Normativity and Power (Oxford: Oxford University Press). Originally in German [2015].

Fraser, Nancy (1989). Unruly Practices: Power, Discourse, and Gender in Contemporary Social Theory (Minneapolis: University of Minnesota Press).

Freeman, Samuel (ed.) (2002). The Cambridge Companion to Rawls (Cambridge: Cambridge University Press).

Freyenhagen, Fabian (2013). Adorno's Practical Philosophy: Living Less Wrongly (Cambridge: Cambridge University Press). 
Freyenhagen, Fabian (2015). 'Honneth on Social Pathologies: a critique'. Critical Horizons 16(2): 131-52.

Freyenhagen, Fabian (2017a). 'Critical Theory's Philosophy'. Cambridge Companion to Philosophical Method, ed. by Giuseppina D'Oro and Søren Overgaard (Cambridge: Cambridge University Press), Ch. 18.

Freyenhagen, Fabian (2017b). 'Was ist Orthodoxe Kritische Theorie' ['What is orthodox critical theory?']. Deutsche Zeitschrift für Philosophie 65(3): 456-69.

Freyenhagen, Fabian (2018). 'Social Pathology and Critical Theory'. Routledge Companion to the Frankfurt School, ed. by E. Hammer, A. Honneth, and P. Gordon (London (etc.): Routledge).

Gauss, Daniel (2013). 'Rational Reconstruction as a Method of Political Theory between Social Critique and Empirical Political Science'. Constellations 20(4): 553-70.

Geuss, Raymond (1981). The Idea of Critical Theory (Cambridge: Cambridge University Press).

Geuss, Raymond (2009). Politics and the Imagination (Princeton, NJ: Princeton University Press).

Habermas, Jürgen (1984). Theory of Communicative Action, Volume 1: Reason and the Rationalization of Society, trans. by T. McCarthy (Boston: Beacon Press). Originally in German [1981].

Habermas, Jürgen (1987). The Philosophical Discourse of Modernity, trans. by F. Lawrence (Cambridge, MA: MIT Press). Originally in German [1985].

Habermas, Jürgen (1992). Postmetaphysical Thinking, trans. by William Mark Hohengarten (Cambridge, MA: MIT Press). Originally in German [1988].

Habermas, Jürgen (1996). Between Facts and Norms, trans. by W. Rehg (Cambridge: Polity Press). Originally in German [1994]. 
Habermas, Jürgen (1998). The Inclusion of the Other: Studies in Political Theory, ed. Ciaran Cronin and Pablo De Greiff, trans. Ciaran Cronin (Cambridge, MA: MIT Press). Originally in German [1996].

Habermas, Jürgen (2002). Religion and Rationality: Essays on Reason, God, and Modernity, ed. by E. Mendieta (Cambridge: Polity Press).

Habermas, Jürgen (2008). Between Naturalism and Religion: Philosophical Essays, trans. by Ciaran Cronin (Cambridge: Polity Press). Originally in German [2005].

Habermas, Jürgen (2012). The Crisis of the European Union; A Response (Cambridge: Polity Press). Originally in German [2011].

Habermas, Jürgen (2017). Postmetaphysical Thinking II Essays and Replies, trans. Ciaran Cronin (Cambridge: Polity Press). Originally in German [2012].

Han-Pile, Beatrice (2002). Foucault's Critical Project: Between the Transcendental and the Historical (Stanford: Stanford University Press).

Honneth, Axel (2000). 'The possibility of a disclosing critique of society: "The Dialectic of Enlightenment" in light of current debates in social criticism'. Constellations $7(1)$ : 116-27. Originally in German [1998].

Honneth, Axel (2005) J. Anderson as The Struggle for Recognition: The Moral Grammar of Social Conflicts, trans. by J. Anderson (Cambridge: Polity Press). Originally in German [1992]

Honneth, Axel (2009). Pathologies of Reason: On the Legacy of Critical Theory (New York: Columbia Press). Originally in German [2007].

Honneth, Axel (2014). Freedom's Right: The Social Foundations of Democratic Life, trans. by J. Ganahl (Cambridge: Polity Press). Originally in German [2011].

Honneth, Axel (2015). 'Rejoinder'. Critical Horizons 16(2): 204-26. 
Horkheimer, Max [1937]. 'Traditionelle und kritische Theorie'. Reprinted in Vol. 4 of Gesammelte Schriften, ed. A. Schmidt, 162-216 (Frankfurt am Main: Suhrkamp, 1988). English translation by M.J. O’Connell in Max Horkheimer, Critical Theory: Selected Essays (New York: Herder and Herder, 1972), 188-243. [Abbreviated as 'TKT' in the text, followed by the pagination in the German edition and the translation, separated by a '/']

Iser, Mathias (2008). Empörung und Fortschritt: Grundlagen einer kritischen Theorie der Gesellschaft [Indignation and Progress: Foundations of a Critical Theory of Society] (Frankfurt am Main: Campus Verlag).

Jaeggi, Rahel (2014). Kritik von Lebensformen (Frankfurt am Main: Suhrkamp).

Jütten, Timo (2011). 'The Colonization Thesis. Habermas on Reification'. International Journal of Philosophical Studies 19(5): 701-27

Jütten, Timo (2015). 'Is the Market a Sphere of Social Freedom?'. Critical Horizons 16(2): 187-203.

Laitinen, Arto; Särkelä, Arvi; and Ikäheimo, Heikki (2015). 'Pathologies of Recognition: An Introduction'. Social \& Political Thought 25: 3-24. Retrieved from http://dx.doi.org/10.20919/sspt.25.2015.44

Marx, Karl (1975). 'Letter to Ruge, September 1843'. In: Karl Marx: Early Writings, trans. by R. Livingstone \& Gregor Benton (London: Pelican Books).

McCarthy, Thomas (2009). Race, Empire, and the Idea of Human Development (Cambridge: Cambridge University Press).

Mills, Charles W. (2017). 'Critizing Critical Theory'. Critical Theory in Critical Times, ed. by Penelope Deutscher and Cristina Lafont (New York: Columbia University Press), Ch. 11. 
Owen, David (2002). Between Reason and History: Habermas and the Idea of Progress (Albany, NY: SUNY Press).

Parr, Adrian (2014). The Wrath of Capital: Neoliberalism and Climate Change (New York: Columbia University Press).

Saar, Martin (2007). Genealogie als Kritik [Genealogy as Critique] (Frankfurt am Main: Campus Verlag).

Schaub, Jörg (2015). 'Misdevelopments, Pathologies, and Normative Revolutions'. Critical Horizons 16(2): 107-30.

Stuckler, David and Basu, Sanjay (2013). The Body Economic (London: Penguin).

Vogelmann, Frieder (2017). 'Measuring, Disrupting, Emancipating: Three Pictures of Critique'. Constellations 24(1): 101-12.

Ypi, Lea (2012). Global Justice and Avant-Garde Political Agency (Oxford: Oxford University Press). 